\title{
MODEL PEMBELAJARAN PEMBIASAAN DALAM MEMBENTUK KARAKTER ISLAMI DAN AKHLAK MULIA PADA PESERTA DIDIK MI NU TARBIYATUL ISLAM LORAM WETAN JATI KUDUS TAHUN 2021/2022
}

\author{
ZAZUK MARDLIYAH \\ MI NU Tarbiyatul Islam Loram Wetan Jati Kudus \\ Email : bilica2putra@gmail.com
}

\begin{abstract}
ABSTRAK
Penelitian ini untuk mengungkap mengetahui: (1) Pelaksanaan model pembelajaran pembiasaan dalam pembentukan karakter Islami dan akhlak mulia pada peserta didik MI NU Tarbiyatul Islam Loram Wetan Jati Kudus. (2) Faktor yang mempengaruhi pelaksanaan model pembelajaran pembiasaan dalam pembentukan karakter Islami dan akhlak mulia peserta didik MI NU Tarbiyatul Islam. Hasil penelitian ini menunjukkan bahwa: (1) Pelaksanaan pembelajaran pembiasaan dalam membentuk karakter islami dan akhlak mulia oleh peserta didik MI NU Tarbiyatul Islam Loram Wetan Jati Kudus meliputi guru merencanakan adanya peraturan agar bisa terkontrol dan berjalan dengan baik, serta peningkatan mutu pembelajaran siswa. Selain itu pengarahan tentang perilaku baik kepada siswa agar tidak melanggar peraturan, dan pemberian nasehat. Begitu juga penanaman kedisiplinan, memberikan pembinaan agar memperbaiki dan meningkatkan budi pekertinya, guru senantiasa menghimbau kepada siswa untuk menjaga perilakunya, dan menetapkan tata tertib bagi siswa untuk selalu memperbaiki dan sopan terhadap semua orang. Setelah memahami antara perilaku baik maka siswa didanjurkan untuk senantiasa melakukan perilaku baik. (2) Faktor yang mempengaruhi pelaksanaan model pembelajaran pembiasaan dalam pembentukan karakter Islami dan akhlak mulia peserta didik MI NU Tarbiyatul Islam Loram Wetan Jati Kudus yakni peran guru yang senantiasa memberi arahan dan bimbingan siswa menjadi anak yang bermoral, pemberian contoh baik juga kisah teladan dari tokoh Islami. Selain itu anjuran untuk menerapkan dalam kegiatan sehari-hari demi tertanamnya kebiasaan yang baik yaitu guru sebagai selalu menjaga dan merawat anak, harus berperan aktif dalam memantau siswa, juga senantiasa memberi arahan dan bimbingan dalam belajarnya agar karakter siswa menjadi anak yang bermoral baik dan sopan terhadap semua orang. Faktor pendukungnya yaitu kesadaran adanya akhlak yang diterapkan dalam kehidupan sehari-hari, peran guru dalam sekolah, pengaruh alat komunikasi yang digunakan dengan baik, mau mengambil teladan yang baik, dan selalu menghormati orang tua, guru dan semua orang. Sedangkan faktor penghambatnya ini tidak adanya perubahan dari tingkah laku siswa setelah pembelajaran, kurang perhatian dan motivasi dari orang tua, pengarahan guru yang tidak diterima dengan baik oleh siswa, juga keterkaitan siswa yang belum bisa merubah sikapnya dan sering melanggar aturan sekolah. Selain itu pengaruh teman yang kurang baik, dan kurangnya kesadaran dalam berakhlakul karimah.
\end{abstract}

Kata Kunci: pembelajaran pembiasaan, karakter Islami, akhlak mulia.

\section{PENDAHULUAN}

Pada hakikatnya pendidikan itu merupakan proses penanaman nilai-nilai seseorang, untuk menjadikan dirinya sebagai orang yang berkepribadian, memiliki kecerdasan dan mempunyai sikap yang mandiri, maka pendidikan secara umum mempunyai peranan yang sangat penting dalam pembentukan kepribadian seseorang termasuk didalamnya pendidikan agama (Hamalik, 2011:182). Pendidikan karakter merupakan sebuah istilah yang semakin hari semakin mendapat pengakuan dari masyarakat saat ini. Terlebih dengan dirasakannya berbagai ketimpangan hal dan perilaku seseorang. Terlebih dalam pembelajaran atau kinerja seseorang. Dalam sebuah pembelajaran dibutuhkan adanya perilaku yang baik atau moralitas siswa yang baik agar siswa tidak membuat kesalahan dan melanggar moral dalam pembelajaran. Untuk menanamkan karakter siswa tersebut dapat dimulai dari diri sendiri. Karena karakter sebagai keseluruhan dari sikap-sikap subjectif emosional, serta mental yang mencirikan watak 
seseorang terhadap lingkungan dan keseluruhan dari reaksi-reaksi itu yang sifatnya psikologis dan sosial.

Secara kodrati manusia akan selalu hidup bersama. Hidup bersama antar manusia akan berlangsung dalam berbagai bentuk komunikasi dan situasi. Dengan demikian, kegiatan hidup manusia akan selalu dibarengi dengan proses interaksi atau komunikasi, baik komunikasi dengan alam lingkungan, interaksi dengan sesamanya maupun interaksi dengan tuhannya baik itu disengaja maupun tidak disengaja (Sardiman, 2010:1). Sebagai makhluk sosial manusia senantiasa ingin berhubungan dengan manusia lainnya. Ia ingin mengetahui lingkungan sekitarnya, bahkan ingin mengetahui apa yang terjadi dalam dirinya. Rasa ingin tahu ini memaksa manusia perlu berkomunikasi (Cangara, 2015:1).

Anak-anak dalam kehidupan bermasyarakat memiliki perilaku yang berbeda-beda, ada yang baik dan ada yang tidak wajar. Selain itu perbuatan baik tidaknya ini terkadang terbentuk karena pengaruh dari lingkungan atau pendidikan yang diterapkan di rumah, di sekolah, bahkan di masyarakat. Seperti halnya yang telah ditayangkan oleh beberapa media yakni ada anak di bawah umur sudah melakukan tindakan asusila, tidak hormat kepada orang tua, bahkan hingga tidak mau menganggap orang tua sendiri atau sampai membunuhnya. Apakah pendidikan moral kita sudah tidak dijalankan ataukah dari anak-anak itu sendiri yang tidak bisa menghambat keinginan-keinginan yang berujung melanggar aturan tatanan agama dan hukum. Manusia dapat merespon dengan perbuatan yang dapat membuat dirinya baik atau buruk, inilah akal pikiran yang dapat menentukan antara melanjutkan atau tidaknya dalam merespon perbuatan itu. Oleh karena itu, moral di sini dapat dipengaruhi oleh rangsangan dari luar, namun manusia itu sendiri yang dapat menentukan dari respon antara melakukan perilaku baik atau mereka belum tergerak dalam melakukan kebaikan.

Apabila dalam kajian Islam, respon yang dilakukan itu menjadi sebuah perbuatan. Perbuatan tersebut nanti termasuk moral yang ada dalam diri manusia. Oleh sebab itu, moral merupakan pendidikan jiwa agar jiwa seseorang dapat bersih dari sifat-sifat yang tercela dan dihiasi dengan sifat-sifat terpuji, seperti sabar, tabah, belas kasih, pemurah dan sifat-sifat terpuji lainnya. Akhlak yang mulia ini merupakan buah dari imannya dan amal perbuatannya. Pendidikan jiwa ini amat penting, sebab jiwa ini merupakan sumber dari perilaku manusia. Maka dari itu, akal dan hati yang dapat mengatur dari respon yang menjadi sebuah perbuatan yang akan dilakukan.

Model pembelajaran pembiasaan di MI NU Tarbiyatul Islam sebagai sarana yang akan mewarnai sikap dan prilaku, dimana anak dalam mengenal lingkungan masyarakat dan dengan adanya pembelajaran pembiasaan diharapkan siswa dapat membentuk karakter Islami dan akhlak yang baik bagi siswa. Oleh karena itu kebiasaan yang baik dapat membentuk karakter Islam siswa dan pribadi yang baik. Karena pembiasaan berpengaruh pada penanaman dan pembentukan karakter siswa dan dapat membantu sebagai arahan siswa dalam bertingkah laku baik serta berkepribadian atau berakhlak sebagaimana menjalankan kebaikan-kebaikan yang sesuai tatanan agama Islam.

\section{METODE PENELITIAN}

Penelitian ini termasuk jenis penelitian lapangan (field research), yaitu sebuah studi penelitian yang mengambil data autentik secara obyektif/studi lapangan (Arikunto, 2013:16). Menurut Norman K. Denzin and Yvonna S. Lincoln, (2000: 2-3) bahwa qualitative research is a field of inquiry in its own right. Qualitative researchers study things in their natural setting, attempting to make sense of, or to interpret, phenomena in therms of the meanings people bring to them. Penelitian Kualitatif adalah bidang penyelidikan dengan sendirinya. Peneliti kualitatif mempelajari berbagai hal dalam lingkungan alami mereka, mencoba memahami, atau menafsirkan, fenomena dalam guncangan makna yang dibawa orang kepada mereka.

Untuk mengetahui pelaksanaan model pembelajaran pembiasaan dalam pembentukan karakter Islami dan akhlak mulia pada peserta didik MI NU Tarbiyatul Islam Loram Wetan Jati Kudus sesuai dengan unsur-unsur pokok yang harus ditemukan yang sesuai dengan butir-butir 
rumusan masalah, tujuan penelitian, maka dalam penelitian ini peneliti menggunakan metode penelitian kualitatif.

\section{HASIL DAN PEMBAHASAN}

1. Pelaksanaan Model Pembelajaran Pembiasaan dalam Pembentukan Karakter Islami dan Akhlak Mulia Pada Peserta Didik MI NU Tarbiyatul Islam Loram Wetan Jati Kudus Tahun $2021 / 2022$

Guru agama Islam diharapkan mampu menanamkan nilai-nilai agama Islam dan dapat menjadi tauladan kepribadian muslim yang kuat, serta pribadi yang baik bagi anak didiknya, karena disebut guru yang professional apabila dapat menunjukkan kualitas dan kemajuan peserta didik dalam pembelajaran. Terkadang di madrasah terdapat faktor yang menghambat atau kendala dalam suatu pengarahan atau pembelajaran. Oleh karena itu guru diharapkan memiliki langkah-langkah tersendiri apabila mengalami hambatan-hambatan yang ada dalam pembelajaran.

Hasil data wawancara dengan Mu'asaroh selaku Kepala MI NU Tarbiyatul Islam bahwa pelaksanaan pembelajaran pembiasaan dalam menerapkan karakter islami dan akhlak mulia yakni:

a. Merencanakan materi yang akan disampaikan.

b. Memilih metode yang paling tepat bagi siswa.

c. Memahami materi.

d. Memberi pengarahan pada siswa, karena inti dari pembelajaran adalah berubahnya sikap.

Adapun pelaksanaan model pembiasaan kami upayakan agar senantiasa terlebih dahulu guru memberi sosialisasi dan contoh baik kepada siswanya agar siswa dapat mengikuti prilakuprilaku yang baik, dan apabila ada siswa yang melakukan prilaku yang kurang baik maka dari kami juga memberikan pembinaan agar memperbaiki dan meningkatkan moral baiknya supaya tidak mempengaruhi teman yang lain. Setelah memahami antara perilaku yang baik maka siswa didanjurkan untuk senantiasa melakukan perilaku yang baik atau akhlak yang mulia. Dengan adanya kebiasaan tersebut siswa senantiasa melakukan dan menghiasi dirinya dengan akhlakul karimah.

Selanjutnya data hasil wawancara dengan Niltas Salam selaku guru di MI NU Tarbiyatul Islam beliau mengatakan bahwa pelaksanaan model pembelajaran pembiasaan dalam membentuk karakter islami dan akhlak mulia di MI NU Tarbiyatul Islam yakni pelaksanaan pembelajaran tersebut yaitu:

a. Guru senantiasa memantau perkembangan moral atau akhlaq mereka dengan adanya nasihat dan pengarahan.

b. Guru memotivasi siswa dalam pembelajaran agar selalu mempersiapkan materi dengan membaca atau mempelajarinya terlabih dahulu.

c. Adanya laporan perilaku yang menjadi perhatian dalam berperilaku di madrasah atau lingkungan sekitar agar senantiasa bermoral yang baik.

d. Pemberian contoh yang baik dari guru juga menjadikan panutan bagi siswa agar mengikuti perilaku yang baik.

e. Guru senantiasa menghimbau kepada siswa untuk menjaga perilakunya, dan jangan melanggar.

f. Menetapkan aturan dan tata tertib bagi siswa untuk selalu memperbaiki dan berperilaku sopan terhadap semua orang.

Selain itu, hasil data wawancara dengan Muhammad Jasri selaku Waka Kesiswaan MI NU Tarbiyatul Islam beliau mengatakan bahwa pelaksanaan pembelajaran model pembiasaan yang diterapkan oleh guru dalam membentuk karakter siswa dan akhlak mulia ini guru merencanakan adanya peraturan-peraturan. Karena dengan perencanaan ini, pembelajaran yang akan dilakukan bisa terkontrol serta berjalan dengan baik. Peningkatan pembelajaran, sebagai cara dalam meningkatkan mutu pembelajaran siswa, adanya kegiatan yang memberikan manfaat atau ada edukasinya. Selain itu pemberian pengarahan akhlaq yang baik kepada siswa 
agar tidak melanggar peraturan, pemberian contoh perilaku yang baik agar siswa mampu mengikutinya. Selain itu juga ketika jam pembelajaran agar mereka dapat belajar tuntas, mengikuti dengan baik. Begitu juga penanaman kedisiplinan waktu, rasa kebersamaan, dan senantiasa menjalankan dengan baik dan tidak melanggar dari perilaku yang tidak baik.

Begitu juga hasil wawancara dengan Syamsul Ma'arif selaku peserta didik MI NU Tarbiyatul Islam Loram Wetan Jati Kudus mengatakan bahwa guru memberi nasehat dan pengarahan berperilaku yang baik, dan apabila ada yang melanggar akan diberi hukuman, atau dipanggil orang tuanya karena melanggar yang menjadikan pencemaran nama baik sekolah, dan dianjurkan untuk terbiasa berakhlakul karimah dalam sehari-hari.

Tabel 1. Hasil Pelaksanaan Model Pembelajaran Pembiasaan dalam Pembentukan
Karakter Islami dan Akhlak Mulia Pada Peserta Didik MI NU Tarbiyatul Islam
\begin{tabular}{|l|l|l|}
\hline No & $\begin{array}{l}\text { Sebelum Pelaksanaan Model } \\
\text { Pembelajaran Pembiasaan }\end{array}$ & $\begin{array}{l}\text { Setelah Pelaksanaan Model } \\
\text { Pembelajaran Pembiasaan }\end{array}$ \\
\hline 1 & $\begin{array}{l}\text { Belum bisa dari tingkah laku siswa } \\
\text { setelah pembelajaran }\end{array}$ & $\begin{array}{l}\text { Membiasakan dan suka } \\
\text { melaksanakan perilaku yang baik } \\
\text { setelah pembelajaran }\end{array}$ \\
\hline 2 & $\begin{array}{l}\text { Sering merespon pengaruh teman } \\
\text { yang kurang baik }\end{array}$ & $\begin{array}{l}\text { Melihat situasi teman dalam } \\
\text { bermain dan memilih mana yang } \\
\text { perilaku yang baik bisa ditiru }\end{array}$ \\
\hline 3 & $\begin{array}{l}\text { Kurang disiplin dalam pembelajaran } \\
\text { dan melaksanakan kegiatan di di dian mengikuti } \\
\text { madrasah }\end{array}$ & $\begin{array}{l}\text { Disiplin dalam mbelajaran dan kegiatan di } \\
\text { pembelan } \\
\text { madrasah }\end{array}$ \\
\hline
\end{tabular}

Hasil peserta didik yang melaksanakan dan perubahan yang dilakukan dalam model pembelajaran pembiasaan ini terdapat pada tabel berikut:

Tabel 2. Hasil Pelaksanaan Model Pembelajaran Pembiasaan dalam Pembentukan Karakter Islami dan Akhlak Mulia Pada Peserta Didik MI NU Tarbiyatul Islam

\begin{tabular}{|l|l|c|}
\hline No & \multicolumn{1}{|c|}{ Hasil Pembelajaran Pembiasaan } & Jumlah Siswa \\
\hline 1 & Terbiasa dengan Prilaku Baik & 138 \\
\hline 2 & Terbiasa dengan pembinaan dan arahan & 224 \\
\hline 3 & Kurang Terbiasa dengan perilaku baik & 32 \\
\hline
\end{tabular}

Adapun digram peserta didik yang melaksanakan dan perubahan yang dilakukan dalam model pembelajaran pembiasaan yang baik sesuai hasil tabel di atas dapat dilihat pada gambar berikut: 

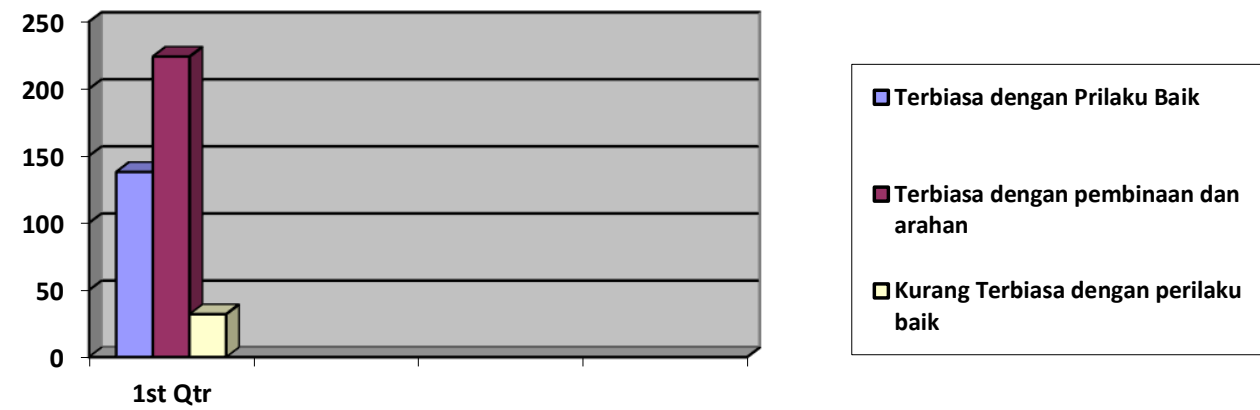

\section{Gambar 1. Diagram Hasil Pelaksanaan Model Pembelajaran Pembiasaan dalam Pembentukan Karakter Islami dan Akhlak Mulia Pada Peserta Didik}

Setelah adanya pembiasaan tersebut, peserta didik tentunya dapat berubah dalam hal perilaku dan karakternya. Perubahan tersebut terlihat dari perilaku siswa. Perilaku yang berubah antara lain yang semula kurang sopan terhadap orang tua, sekarang senantiasa berlaku baik dengan pembiasaan dan diberikan pengarahan. Selain itu, anjuran untuk sholat tepat waktu dengan pembiasaan ketika sholat dhuhur berjamaah di masjid dapat meningkatkan perubahan yang baik bagi siswa dengan pembinaan dan pembiasaan ketika di rumah. Hal ini menandakan pembiasaan dengan karakter islami selain berperikau baik dan sopan, juga melaksanakan kegiatan yang baik menurut agama Islam.

Langkah-langkah yang diterapkan oleh guru dalam dalam membentuk karakter islami dan akhlak siswa siswa melalui model pembelajaran pembiasaan di MI NU Tarbiyatul Islam meliputi guru merencanakan adanya peraturan-peraturan agar bisa terkontrol serta berjalan dengan baik. Peningkatan pembelajaran, sebagai cara dalam meningkatkan mutu pembelajaran siswa, adanya kegiatan. Selain itu pemberian pengarahan akhlaq yang baik kepada siswa agar tidak melanggar peraturan, pemberian nasehat dan pengarahan berperilaku yang baik, dan apabila ada yang melanggar akan diberi hukuman. Begitu juga penanaman kedisiplinan waktu, memberikan pembinaan agar memperbaiki dan meningkatkan moral baiknya supaya tidak mempengaruhi teman yang lain.

Melalui uraian di atas, maka upaya guru dalam pembelajaran pembiasaan dalam membentuk karakter islami dan akhlak peserta didik di MI NU Tarbiyatul Islam dapat dilakukan dengan menerapkannya dalam kehidupan sehari-hari dan dengan adanya pembiasaan. Pembentukan kepribadian muslim disini dapat terbentuk melalui kebiasaankebiasaan perilaku yang dilakukan, maka apabila anak didik dibina dan dididik dengan kebiasaan baik maka anak didik tersebut akan tumbuh dengan perilaku yang baik. Sebaliknya apabila anak didik itu dibina dengan kebiasaan jelek maka anak didik tersebut akan tumbuh dengan perilaku yang jelek karena hal-hal yang sering dilakukan itu telah menjadi kebiasaan.

Begitu juga manusia itu telah dibekali kesadaran moral atau perasaan berakhlak sebagai

fitrah yang telah dibawanya sejak lahir. Dengan istilah lain bahwa kesadaran moral atau perasaan untuk berbuat baik merupakan pembawaan manusia sejak lahir. Perbuatan yang lahir dari kesadaran ini disebut dengan perbuatan berakhlak, yaitu perbuatan yang sesuai dengan norma-norma akhlak atau moral (Asmaran As, 2009:40).

Kesadaran moral atau perasaan berakhlak ini timbul dari hati. Ia memerintahkan agar melakukan kewajiban dan memerintahkan supaya jangan menjauhinya, walaupun kita tidak mengharapkan balasan atau takut siksaan. Jika kita menemukan sebuah barang di jalan, tidak seorangpun yang melihat, kecuali Tuhannya, kemudian ia sampaikan barang tersebut kepada pemiliknya, maka apakah yang mendorongnya berbuat demikian? Tidak lain kecuali hatinya memerintahkannya agar menepati kewajiban, bukan karena mengharapkan balasan atau takut siksaan akibat perbuatan itu.

Orang memiliki kesadaran moral akan senantiasa jujur. Sekalipun tidak ada orang lain yang melihatnya, tindakan orang yang bermoral tidak akan menyimpang, dan selalu berpegang 
pada nilai-nilai tersebut. Hal ini terjadi karena tindakan orang yang bermoral itu berdasarkan atas kesadaran, bukan karena paksaan, tetapi berdasarkan kesadaran moral yang timbul dari dalam diri yang bersangkutan.

Menurut Nur Uhbiyati (2015:135), kebiasaan mempunyai peranan penting dalam kehidupan manusia, karena ia menghemat banyak sekali kekuatan manusia, karena sudah menjadi kebiasaan yang mudah melakat dan spontan agar kekuatan itu dapat dipergunakan untuk kegiatan-kegiatan di lapangan lain seperti untuk bekerja, mereproduksi dan mencipta. Bila pembawaan seperti itu tidak diberikan tuhan kepada manusia, maka tentu mereka akan menghabiskan hidup mereka hanya untuk belajar berjalan, berbicara, berhitung. Tetapi disamping itu kebiasaan juga merupakan faktor penghalang terutama bila tidak ada penggeraknya dan berubah menjadi kelambanan yang memperlemah dan mengurangi reaksi jiwa. Islam mempergunakan kebiasaan itu sebagai salah satu teknik pendidikan, lalu mengubah seluruh sifat-sifat baik menjadi kebiasaan, sehingga jiwa dapat menunaikan kebiasaan tanpa susah payah, tanpa kehilangan banyak tenaga dan tanpa menemukan banyak kesulitan.

Oleh karena itu upaya guru dalam membentuk karakter islami dan akhlak siswa melalui model pembiasaan dapat dilakukan sehari-hari agar moral dapat terbentuk dalam diri siswa. Karena tujuan pembentukan karakter siswa melalui model pembiasaan adalah membantu kepada orang perorangan atau kelompok dengan memberikan pengarahan diri, mengarahkan siswa agar dapat berperilaku baik dan sopan serta memperoleh kebahagiaan hidup serta mewujudkan diri sesuai dengan hakekatnya sebagai manusia yang selaras perkembangan unsur dirinya dan kedudukannya sebagai makhluk Allah. Maka guru pembimbing di sini dapat membantu siswa-siswanya yang telah melanggar aturan madrasah dengan membiasakan memberi pengarahan dan penyuluhan kepada siswa-siswa tersebut.

Melalui uraian di atas, maka upaya guru dalam membentuk karakter islami dan akhlak siswa melalui model pembelajaran pembiasaan harus dilaksanakan dalam sekolah, juga pembentukan karakter siswa tersebut selalu diberikan kepada siswa-siswanya dengan pengarahan dan penyuluhan mengenai perilaku-perilaku yang baik dan tidak melanggar akhlak yang tidak sesuai agar siswa dapat melaksanakan dan membiasakan dengan sikap yang terpuji sesuai dengan aturan dan norma yang berlaku. Begitu juga siswa dapat menerapkan sikap-sikap yang terpuji baik di sekolah, masyarakat, maupun di lingkungan sekitarnya agar moral siswa dapat terbentuk melalui pembiasaan sikap-sikap dan perilaku yang terpuji itu.

2. Faktor yang Mempengaruhi Pelaksanaan Model Pembelajaran Pembiasaan Dalam Pembentukan Karakter Islami Dan Akhlak Mulia Peserta Didik MI NU Tarbiyatul Islam Loram Wetan Jati Kudus Tahun 2021/2022

Moral merupakan istilah yang digunakan untuk memberikan batasan terhadap aktivitas manusia dengan nilai/hukum baik dan buruk, benar atau salah. Dalam kehidupan sehari-hari dikatakan bahwa orang yang mempunyai tingkah-laku yang baik disebut orang yang bermoral. Moral merupakan kaidah norma dan pranata yang mengatur perilaku individu dalam hubungannya dengan kelompok sosial. Akhlak atau moral merupakan pendidikan jiwa agar jiwa seseorang dapat bersih dari sifat-sifat yang tercela dan dihiasi dengan sifat-sifat terpuji, seperti rasa persaudaraan dan saling tolong menolong antar sesame manusia, sabar, tabah, belas kasih, pemurah dan sifat-sifat terpuji lainnya. Akhlak yang mulia ini merupakan buah dari imannya dan amal perbuatannya.

Guru agama Islam diharapkan mampu menanamkan nilai-nilai agama Islam dan dapat menjadi tauladan kepribadian muslim yang kuat, serta pribadi yang baik bagi anak didiknya, karena disebut guru yang professional apabila dapat menunjukkan kualitas dan kemajuan peserta didik dalam pembelajaran. Dalam penyampaian materi terkadang ada faktor yang menghambat dan faktor pendukung dalam pembelajaran. Oleh karena itu guru diharapkan memiliki langkah-langkah tersendiri apabila mengalami hambatan-hambatan yang ada dalam pembelajaran. 
Hasil data wawancara dengan Mu'asaroh selaku Kepala MI NU Tarbiyatul Islam tentang faktor yang mempengaruhi karakter Islami dan akhlak siswa MI NU Tarbiyatul Islam beliau mengatakan bahwa faktor yang mempengaruhi bagi siswa bahwa guru senantiasa memberi arahan dan bimbingan dalam belajarnya agar karakter siswa menjadi anak yang bermoral baik, selain itu pemberian contoh yang baik juga kisah-kisah teladan yang perlu disampaiakan kepada siswa agar mereka mengerti karakter islami seperti teladan para nabi dan shahabat yang perlu diteladani bagi guru dan siswa. Setelah itu anjuran untuk menerapkan dalam kegiatan sehari-hari demi tertanamnya kebiasaan yang baik kepada siswa.

Selanjutnya data hasil wawancara dengan Niltas Salam selaku guru di mengatakan bahwa faktor yang mempengaruhi karakter islami yang ini kami memberikan amanat atau pesan kepada siswa apabila pembelajaran diharapkan mengambil contoh yang baik dari cerita atau materi pembelajaran, selain itu bimbingan orang tua dan adanya peraturan atau tata tertib agar siswa dapat senantiasa berperilaku baik sesuai ajaran islam dan tidak melanggar peraturan yang tidak diperbolehkan oleh agama.

Selain itu data hasil wawancara dengan Muhammad Jasri selaku Waka Kurikulum MI NU Tarbiyatul Islam beliau mengatakan bahwa faktor yang mempengaruhi dalam menanamkan karakter islami di sini peran guru yang senantiasa memberi pengarahan siswa untuk senantiasa berlaku sopan dan tata krama terhadap guru. Selain itu juga adanya unggah-ungguh atau tawadu' terhadap gurunya sendiri meskipun di lingkungan sekitar seperti halnya teman sendiri, pemberian kisah teladan dari tokoh Islam yang dapat memberikan contoh teladan baik bagi siswa.

Kemudian, hasil data wawancara dengan Syamsul Ma'arif selaku peserta didik MI NU Tarbiyatul Islam Loram Wetan Jati Kudus bahwa Faktor yang mempengaruhi yaitu, peran guru sebagai pengganti orang tua untuk selalu menjaga dan merawat siswa, juga mengarahkan dengan perilaku yang baik. Karena guru itu sebagai penuntun atau yang membimbing, merawat, dan menjaga siswa, selain itu ada guru yang kesadaran dari siswa sendiri untuk memperhatikan perilakunya agar senantiasa tidak terjerumus dalam perilaku yang kurang baik.

Dari uraian di atas dapat dikatakan bahwa akhlak lebih mengacu kepada suatu nilai atau sistem hidup yang dilaksanakan atau diberlakukan oleh masyarakat. Nilai atau sistem hidup tersebut diyakini oleh masyarakat sebagai yang akan memberikan harapan munculnya kebahagiaan dan ketentraman. Nilai-nilai tersebut ada yang berkaitan dengan perasaan wajib, rasional, berlaku umum dan kebebasan. Jika nilai-nilai tersebut telah mendarah daging dalam diri seseorang maka akan membentuk kesadaran moralnya sendiri. Orang yang demikian akan dengan mudah dapat melakukan suatu perbuatan tanpa harus ada dorongan atau paksaan dari luar. Orang yang demikian adalah orang yang memiliki kesadaran moral, atau orang yang telah bermoral.

Sekolah merupakan peran penting dalam dunia pendidikan. Peran serta sekolah tidak kalah pentingnya jika dibandingkan dengan rumah dan lingkungan masyarakat, walaupun nilai urgensinya berbeda-beda sesuai dengan waktu, lokasi, dan faktor-faktor kebudayaan yang mempengaruhinya. Oleh karena itu, sejak awal sekolah harus diarahkan agar dapat beroperasi sejalan dengan dengan tingkat pengetahuan masyarakat dan pendidikan yang dilakukan oleh orang tua di rumah. Hal itu dimaksimalkan untuk mencapai target pendidikan yang telah digariskan, merealisasikan sasaran yang telah dibuat, sama-sama memiliki rasa tanggung jawab dalam mempersiapkan generasi yang baik dan maju, dan membangun pribadi-pribadi agung yang sehat dan benar dalam akidah dan moralnya.

Uraian tersebut menjadi tugas mulia bagi para pengajar atau guru bahwa tenaga pengajar atau guru merupakan batu fondasi dalam proses pendidikan dan aktivitas dakwah. Pengajar merupakan unsur pendidikan pertama yang berperan untuk mewujudkan tujuan dan prinsip yang diyakini. Pengajar merupakan harapan semua orang untuk memberikan penyadaran, penyuluhan dan evaluasi. Kemampuan yang dimiliki oleh guru sangat berpengaruh terhadap penyiapan generasi yang akan datang dan pendidikannya secara keilmuan, moral dan akhlak. Guru sangat berperan dalam mengarahkan siswa dan generasi muda untuk menyelamatkan 
mereka dari kehinaan dan sikap tidak terpuji, mengeluarkannya dari kebodohan menuju petunjuk Ilahi yang terang, menjaganya dari kerusakan dan penyimpangan, dan mengembalikannya kepada syariat Allah (Al-Zuhaili, 2014:107-108).

Faktor pendukung lain selain guru adalah faktor yang berasal dari siswa. Siswa sebagai obyek atau sasaran pembelajaran akan sangat mendukung sekali karena pada hakekatnya kegiatan pembelajran merupakan proses interaksi antara obyek dan subyek pendidikan, yaitu guru dan siswa. Hal ini mengindikasikan bahwa siswa harus berupaya untuk lebih aktif dan melatih untuk percaya diri dalam mengemukakan pendapat sehingga persepsi yang selama ini menganggap bahwa siswa hanyalah sebagai penerima ilmu pengetahuan harus segera dirubah, karena dengan metode diskusi ini siswa berusaha untuk menjadi penemu, yaitu menemukan ilmu pengetahuan melalui pengalaman yang dimilikinya.

Guru juga merupakan contoh bagi yang lainnya dalam akhlak, cara berpikir, dan mentalnya. Sebagaimana halnya Rasulullah Saw. adalah panutan dan ikutan bagi seluruh orang beriman, para guru dan pendidik harus bisa menjadi teladan dan contoh bagi para siswa dan masyarakat, baik ketika berada di sekolah, masjid, maupun tempat lain.

Peran guru menanggung beban tanggung jawab untuk memperbaiki keadaan, meluruskan kondisi dan melakukan penyuluhan yang benar. Jika gagal, mereka akan mempertanggung jawabkan semua itu kepada generasi yang akan datang. Siswa atau murid yang berada di sekolah menjadi amanah yang dipikulkan kepada guru dan pendidik. Keluarga, masyarakat, dan negara telah memberikan keleluasaan kepada mereka dalam melaksanakan pendidikan. Mereka diberikan tugas untuk mendidik anak-anak agar menjadi orang yang beradab. Para guru dan pendidik diberikan kewenangan dalam memberikan penyuluhan, arahan, dan pembinaan agar anak-anak menjadi baik dan memiliki keutamaan yang terpuji. Guru memiliki peran dalam menjaga perkembangan jiwa anak, memberikan hak-hak yang harus mereka dapatkan, mengawasinya, memelihara urusan mereka, dan melindungi mereka dari usaha pembunuhan dan pembantaian moral dari para musuh kebajikan.

\section{KESIMPULAN}

Pelaksanaan pembelajaran pembiasaan dalam membentuk karakter islami dan akhlak mulia oleh peserta didik MI NU Tarbiyatul Islam Loram Wetan Jati Kudus meliputi guru merencanakan adanya peraturan agar bisa terkontrol dan berjalan dengan baik, serta peningkatan mutu pembelajaran siswa. Selain itu pengarahan tentang perilaku baik kepada siswa agar tidak melanggar peraturan, dan pemberian nasehat. Begitu juga penanaman kedisiplinan, memberikan pembinaan agar memperbaiki dan meningkatkan budi pekertinya, guru senantiasa menghimbau kepada siswa untuk menjaga perilakunya, dan menetapkan tata tertib bagi siswa untuk selalu memperbaiki dan sopan terhadap semua orang. Setelah memahami antara perilaku baik maka siswa didanjurkan untuk senantiasa melakukan perilaku baik.

Faktor yang mempengaruhi pelaksanaan model pembelajaran pembiasaan dalam pembentukan karakter Islami dan akhlak mulia peserta didik MI NU Tarbiyatul Islam yakni peran guru yang senantiasa memberi arahan dan bimbingan siswa menjadi anak yang bermoral, pemberian contoh baik juga kisah teladan dari tokoh Islami. Selain itu anjuran untuk menerapkan dalam kegiatan sehari-hari demi tertanamnya kebiasaan yang baik yaitu guru sebagai selalu menjaga dan merawat anak, harus berperan aktif dalam memantau siswa, juga senantiasa memberi arahan dan bimbingan dalam belajarnya agar karakter siswa menjadi anak yang bermoral baik dan sopan terhadap semua orang. Faktor pendukung dan penghambat pelaksanaan model pembelajaran pembiasaan dalam pembentukan karakter islami siswa dan akhlak mulia pada peserta didik MI NU Tarbiyatul Islam Loram Wetan Jati Kudus yaitu kesadaran adanya akhlak yang diterapkan dalam kehidupan sehari-hari, peran guru dalam sekolah, pengaruh alat komunikasi yang digunakan dengan baik, mau mengambil teladan yang baik, dan selalu menghormati orang tua, guru dan semua orang, menerapkan budi pekerti yang baik. Sedangkan faktor penghambat dalam pelaksanaan pembelajaran pembiasaan ini tidak 
adanya perubahan dari tingkah laku siswa setelah pembelajaran, kurang perhatian dan motivasi dari orang tua, pengarahan guru yang tidak diterima dengan baik oleh siswa, juga keterkaitan siswa yang belum bisa merubah sikapnya dan sering melanggar aturan sekolah. Selain itu pengaruh teman yang kurang baik, dan kurangnya kesadaran dalam berakhlakul karimah.

\section{DAFTAR PUSTAKA}

Al-Zuhaili, Muhammad. (2014). Menciptakan Remaja Dambaan Allah (Panduan Bagi Orang Tua Muslim). Bandung: PT. Mizan Pustaka.

Arikunto, Suharsimi. (2013). Prosedur Penelitian. Jakarta: Rineka Cipta.

As, Asmaran. (2012) Pengantar Studi Akhlak. Jakarta,CV. Rajawali Pers.

Cangara, Hafied. (2015). Pengantar Ilmu Komunikasi. PT. Rajafindo Persada, Jakarta.

Denzin, Norman K., and Lincoln. (2000) Yvonna S., Handbook of Qualitative Research. India: New Delhi.

Fathoni, Abdurrahmat. (2016). Metodologi Penelitian dan Tehnik Penyusunan Penelitian. Jakarta: Rineka Cipta.

Hamalik, Oemar. (2011). Proses Belajar Mengajar. Jakarta:Bumi Aksara.

Lickona, Thomas. (2016). Mendidik Untuk Membentuk Karakter Bagaimana Sekolah Dapat Mengajarkan Sikap Hormat dan Tanggung Jawab. Jakarata: PT. Bumi Aksara.

Moleong, Lexy J., (2013). Metode Penelitian Kualitatif. Bandung: PT. Remaja Rosdakarya.

Nasution, S. (2013). Metode Research (Penelitian Ilmiah). Jakarta:Bumi Aksara.

Sugiyono. (2014). Metode Penelitian Pendidikan Pendekatan Kuantitatif, Kualitatif, dan R\&D. Bandung: Alfabeta.

Uhbiyati, Nur. (2015). Ilmu Pendidikan Islam I. Bandung:Pustaka Setia. 